\title{
The Effect of Collaborative Writing on EFL Students' Grammatical Accuracy
}

\author{
Hussein Meihami $^{1, *}$, Bahram Meihami $^{2}$, Zeinab Varmaghani ${ }^{3}$ \\ ${ }^{1}$ Department of English Language Teaching, Ghorveh Branch, Islamic Azad University, Ghorveh, Iran \\ ${ }^{2}$ Department of Accounting, Ghorveh Branch, Islamic Azad University, Ghorveh \\ ${ }^{3}$ BA Student of Primary Education, Ghorveh Branch, Islamic Azad University, Gr veh, Iran \\ *E-mail address: hussein.meihami@yahoo.com

\section{ABSTRACT}

Writing is considered as an activity which is done ind ally a the role of thumb for its feedback is thought to be provided by teachers and instry urors. Although $\mathcal{C}$ has been a growing body of research on using pair and small group activiti in second or foreng language learning in relation to oral skill (e.g. Speaking), on writing there are ly a few we"-documented researches. This research describes a study exploring the effect of collabo ve writing on EFL student's grammatical accuracy in their writing. A total of 50 Iranian Advanced st range of 20 to 24 participated in this study. The were engaged in tasks in which they worked on each other's writing and gave feedback on gr mmà ints to each other. Obtaining corrective feedback from their fellows, enabled students pinpent their grammatical errors better and subsequently improve their grammat curacy it their upcoming writings. The results suggest that collaborative writing $(\mathrm{CW})$ is b eficia in allow $\mathrm{EFL}$ learners to make gain in grammatical accuracy.

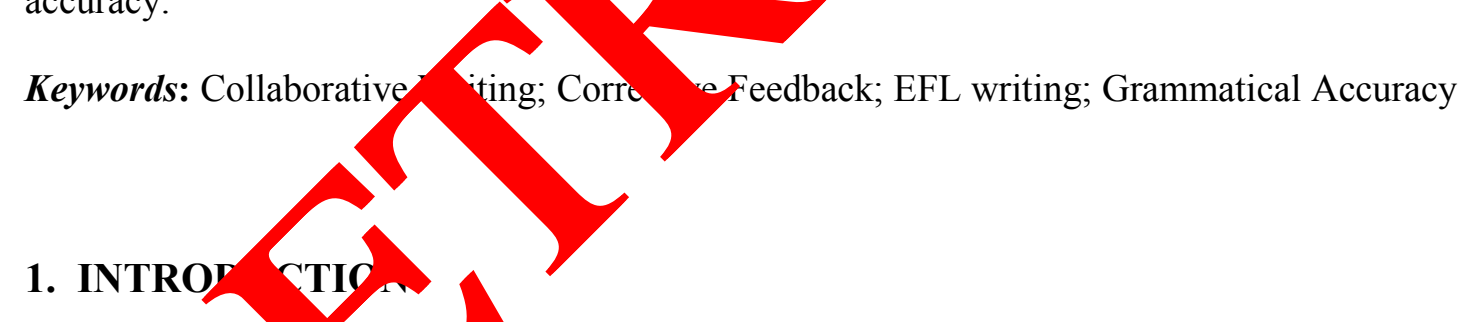

much the early research in the second language context examined the nature
of labo tive talk id/or the role of the first language in second language learning (Swain learnin ncluding collaborative writing activities. Mancho'n (2011, p. 46), argued that the "rational $A$ the language learning potential of writing derives from various influential theoreticalstrands of SLA research"' (Williams, 2012). In relation to collaborative writing, of importance is a theoretical construct which reflects the increasing realization of the relevance of the social context of language learning. Consideration of social context is frequently underpinned by the adoption of a culture of society theoretical approach which provides a means to understand and elucidate the learning process. It is within this construct that collaborative writing has been used to explore how social interaction contributes to learning, feedback, and our understanding of, and insights into, both of these. 
From a theoretical perspective, the use of pair and group work in the L2 classroom is supported by the social constructivist perspective of learning. The social constructivist perspective of learning, originally based on the work of Vygotsky (1978), posits that human development is inherently attracting by social activity. In First Language (L1) contexts, the child's cognitive and linguistic development arises in social interaction with more able members of society (experts), who provide the novice with the appropriate level of assistance (Gillian and Neomy, 2012, Alegri'a de la Colina \& Garc1'a Mayo, 2007; Donato, 1994; Kim, 2008; Kuiken \& Vedder, 2002a; Nassaji \& Tian, 2010; Storch, 2002; Swain, 1998; Swain, 2000; Swain, 2006; Swain, 2010; Swain \& Lapkin,1998; Swain \& Lapkin, 2001; Swain \& Lankin, 2002; Swain, Lapkin, Knouzi, Suzuki, \& Brooks, 2009). In particular, these rese ichers shown that DICTOGLASS tasks (tasks in which students reconstruct in $p$ or group. text read by the teacher as closely as possible to the original text) were success filly. implish by learners as a collaborative or joint activity, and hat such jointly perormed tas nab ed learners to solve linguistic problems that lied beyond their individu? gbiliti Furtho whese researchers have found on delayed posttests that there was a str $7 \mathrm{~g}$ 'ncy fo students to stick with the knowledge that they had constructed collab ratively, tor rong (e.g., Swain, 1998; Swain \& Lapkin,1998 as cited in Gillian and Nor 2012).

On the pedagogical side, several researchers have on hasiz the multiple benefits of collaborative pair and group work in L2 learning. For ins
evidence from pedagogically-oriented research, states $t$ at:

Pair and small group activities provide lear s with mo time to speak the target language than teacher-fronted activities, promote learm autono y and self-directed learning, and give instructors opportunities to work individum arners. In addition, learners may feel less anxious and more confident when $i$, term with peers during pair or small group activities than during whole-class discussions.

As such, due to both theor uca nd peda ogical considerations, it has been concluded that learners should be encoy do articipate $/ n$ activities that foster collaboration in the L2 classroom.

Now in the prese study, w e heading for investigating the effect of collaborative activities in writing to $4 \mathrm{~F}$. ydents to $\mathrm{aw}$ the finding in the case of grammatical accuracy. To put in another word th rese. is heading to see the impact of CW on grammatical accuracy.

\section{2. Review o it rature}

The intere $\mathrm{s}$ in such resea $\mathrm{ems}$ from both theoretical and pedagogical considerations.

dis urse, search in estigating the benefits of collaborative work for the written discourse in
L2, For ins. Storch ( 2005, p.153) states that "although pair and group work are commonly used in languag assrooms, very few studies have investigated the nature of such collaboration when students produce a jointly written text.' Storch points out that most past studies on collaborative work in the L2 classroom ' have examined learners' attitudes to group/pair work in general, rather than to the activity of collaborative writing'" (p. 155). More important for the purpose of this study, Storch also stresses the novelty represented by the pedagogical strategy of having students composing in pairs (p. 168).

Researches on pair and group work in L2 writing have investigated and documented the benefits of group feedback (e.g., Connor \& Asenavage,1994; Hedgcock \& Lefkowitz, 1992; Rollinson, 2004; Zhu, 2001), or issues relating to group dynamics, various types of 
group formations, and how groups function in peer review tasks (e.g., Levine, Oded, Connor \& Asons, 2002; Lockhart \& Ng, 1995; Mangelsdorf \& Schlumberger, 1992; Mendonca \& Johnson, 1994; Nelson \& Murphy, 1992; Nelson \& Murphy, 1993; Villamil \& De Guerrero, 1996), rather than collaborative writing. The studies that have investigated CW in L2 were carried out by Kuiken and Vedder, 2002b, Storch, 2005, and Storch and Wigglesworth (2007, 2010a, b). These studies are reviewed below.

In a cross-sectional study that concentrated on collaborative dialogues, dictogloss, and text reconstruction tasks, Kuiken and Vedder,2002b investigated the role of group interaction in L2 writing. They tested the hypothesis that "text quality in L2 is paritively affected by collaborative dialogue: when learners are given the opportunity recons together a text, which has been read to them by the teacher, their joint y duct will better than an individual reconstruction" (p.169). The investigators colle ${ }^{\text {ted }}$. from intermediate proficiency level learners of Dutch, English, and Italian a a second gua se. They focused on the syntactic and lexical quality of the text $p^{r}$ uced a ho it is affected by the degree to which learners interact with each otb a kind of metacognitive, linguistic, and interaction strategies they used ( $\mathrm{i}^{\mathrm{i}}$ ian and my, 2012). The investigators found that there was a strong relationship betwee $\Lambda$ action an writers on meta-linguistic awareness and text quality in L2. That is, le ners lection on and discussion of language forms, content, and the writing process resulte $/$ noticing and, as a consequence, better knowledge of certain grammatic and lexical fory 1 s. Kuiken and Vedder argued that these findings show that collaborative lan age produc lon can prompt learners to deepen their awareness of linguistic rules and tris cognitiv processes that might both generate new linguistic knowledge and consolidate knowledge. They also argued that meta-talk can help learners understan olation between form and meaning, and positively affect acquisition of L2 knowle ge. om 2005 investigated the process and product of CW and students' views on it. 'ne colrected data from 23 adult ESL students completing degree courses at larg Austral n university. Students were given a choice to write in pairs or individually. teen students chose to work in pairs and five chose to work individually. The produced by pairs with those produced by individual learners. The dy also ited learners' reflections and views on the experience of CW. Storch foy a pairs p duced shorter but better texts in terms of task fulfillment, gramm tiol acc $\mathrm{V}$, and complexity, suggesting that pairs seem to fulfill the task more competently. Sho so found that most students were positive about the experience, hougt some did express reservations about CW. Storch concluded that collaboration a ded stu nts the opportunity to pool ideas and provide each other with immed feedbà

In a nilar stu, Storch and Wigglesworth (2007) compared the writings of individuals ana is the same writing tasks. They also studied how pairs approached the task on iting and how they interacted as they were completing the activity. university.)

Tho stigators collected data from 72 postgraduate students at a large Australian

The participants' proficiency level in English was advanced. Twenty-four of the participants completed two writing tasks individually, and 48 (24 pairs) completed the two tasks in pairs. Like Storch (2005), the investigators found that pairs tended to produce texts with greater accuracy than individual writers. They found that collaboration afforded students the opportunity to engage with and about language, and to work at a higher level of activity than the case where they were working alone. Storch and Wigglesworth concluded that: 
collaboration afforded the students the opportunity to interact on different aspects of writing. In particular, it encouraged students to collaborate when generating ideas and afforded students the opportunity to give and receive immediate feedback on language, an opportunity missing when students write individually (p.172).

More recently, Storch and Wigglesworth $(2010 \mathrm{a}, \mathrm{b})$ conducted a four-week period study. The study consisted of three sessions. In session 1 (Day 1), 48 advanced proficiency level learners worked in pairs ( 24 pairs) to compose a text based on a graphic prompt. In session 2 (Day 5), the learners reviewed the feedback they received from their teacher and jointly rewrote their text. In session 3 (Day 28), each of the learners compo individually using the same prompt as in session 1 . The texts produced by t'e pairs a the feedback (Day 5) were analyzed for evidence of uptake of the feedbar rovided the teacher (reformulations or direct feedback vs. editing symbols or ind fec ck), a d texts produced be students individually in session 3 for evidence of rete cion. The inv ors found that "uptake and retention may be affected by a host of ruist and a ective factors, including the type of errors the learners make in their w a more ir portantly, learners' attitudes, beliefs, and goals"' (Storch \& Wigglesworth 10a, p.

As it can be seen from this review of literature, there an $h$ ' $t$ v researc os in relation to $\mathrm{CW}$ and its effect on grammatical accuracy. So the fir am of current research is to investigate this important matter.

Another important basis for the current udy is the potential of writing for language learning in general, and in foreign langua (FL) cont xts in particular (see, e.g., Mancho'n, 2009a; Mancho'n, 2009b; Ortega, 2004; 'ega, 20 9; Polio \& Williams, 2009). These scholars have spoken of the ne to exten w writing research beyond the traditional second language (SL) settings to nom contexts.

As can be seen from the relevant lite to re rewed above, however, most existing research on $\mathrm{CW}$ in $\mathrm{L} 2$ to date ho used o SL rather than FL contexts (see Kuiken \& Vedder, 2002b, Storch, 2005; Corch Wiggle Jorth, 2007, 2010a, b). The ultimate aim of the current research is ther investigate the potential collab ive writing in these contexts.

The following ro o c questio formulated for the purpose of this study:

A) Does collabo tive ting hav $\ell$ any effect on improving grammatical accuracy on EFL stud writing

\section{METHODQ GY}

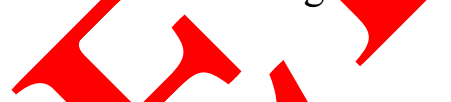

\section{1 Rese ch $\mathrm{Hyp}$ cesis}

hesis was run in this research. Collaborative writing doesn't have any effect o. 'nproving grammatical accuracy on EFL students' writing.

\section{2. Participants}

A total of 50 advanced EFL students of English language learning all male and with age range of 20 to 24 were participating in this study. All of these students were Iranian and English was a foreign language for them. English was taught in an EFL context. They were recruited to participate voluntarily in an English composition program (ECP). The program was provided by the University of Raja in the spring of 2013. The aim of the program was to enable students to write in English and to improve their writing ability for the future course in 
essay writing. The program started in April the 6 and finished in June the 6 of 2013. It took two month period and 24 sessions. Each week there were three sessions each took 1 and a half hour. For the purpose of the research students were divided into two groups. Prior to the starting of classes and in the registration day students were informed about a pretest in the second session.

\section{3. Materials}

There was a pretest-posttest design in this research. For this purpose, two pieces of writings were required. In the second session of the program, the pretest was run the $24^{\text {th }}$ session the posttest was held. The topic for the pretest and posttest writino o was cho as "the needs for learning English in today's life". The participants were in aa ed level proficiency so writing about this topic wasn't hard for them. For procedure was used which was once proposed by Brown and Bailey able 1 is in $\mathrm{r}$, this rating procedure features.

Table1. Analytic scale for rating composition scale (Br

\begin{tabular}{|c|c|c|c|c|c|}
\hline & $\begin{array}{l}100-81 \\
\text { Excellent to } \\
\text { Good }\end{array}$ & $\begin{array}{l}80-71 \\
\text { Good to } \\
\text { Adequate } \\
\end{array}$ & $\begin{array}{l}70-51 \\
\text { Adequ } \\
\text { Fair } \\
\end{array}$ & $\begin{array}{l}50 \\
\text { Unaco able }\end{array}$ & $\begin{array}{l}30-10 \\
\text { Very } \\
\text { Weak }\end{array}$ \\
\hline Grammar & $\begin{array}{l}\text { Native-like } \\
\text { fluency in } \\
\text { English } \\
\text { grammar; } \\
\text { Correct use } \\
\text { of relative } \\
\text { clause, } \\
\text { preposition, } \\
\text { models, } \\
\text { articles, } \\
\text { verb for s, }\end{array}$ & $\begin{array}{l}\text { Advanced } \\
\text { proficienc } \\
\text { English } \\
\text { grammar; } \\
\text { grammar } \\
\text { problep } \\
\text { infly nce } \\
\text { cam }\end{array}$ & a par & $\begin{array}{l}\text { Imerous } \\
\text { erious } \\
\text { grammar } \\
\text { problems } \\
\text { interfere with } \\
\text { the } \\
\text { communication } \\
\text { of the writer's } \\
\text { idea; grammar } \\
\text { review in some } \\
\text { points are } \\
\text { needed }\end{array}$ & $\begin{array}{l}\text { Severe } \\
\text { grammar } \\
\text { problems } \\
\text { interfere } \\
\text { with the } \\
\text { message; } \\
\text { reader } \\
\text { can't } \\
\text { understand } \\
\text { what the } \\
\text { writer was } \\
\text { trying to } \\
\text { say }\end{array}$ \\
\hline
\end{tabular}

\section{4. Procédure}

The 50 EFL advanced students were divided into two classes: class A and class B. In class A, collaborative writing was the desired treatment. In each session from the second session on, the teacher gave a subject to the students to write about. In the following session students came back with their writings, but they didn't give them to their teacher to give corrective feedback on them. Instead, they gave their writings to their partners to give CF on them. They consulted the problematic parts with each other and did their best to make their 
composition better. In each piece of paper there were two split places for scoring and feedback. One of these places was devoted to students' partner to give their feedback and utterly their score; on the other hand, there was a place for the teacher to assess the feedback which was given by partners to their friend's composition. To give a gist of it, each session students were working on each other's writings then the paper gathered and delivered to the teacher and he assessed the given feedback by students in the following session. 21 sessions had passed in this way. During these sessions, collaborative writing (CW) was quite observable due to the sense of humor and friendship that it caused. Students were working on each other's writing with a great passion. In class B; however, there wasn't any ${ }^{\mathrm{r}_{\mathrm{s}}}$ in relation with collaborative writing.

The same procedure like class A was run in relation to pretest, and ttest. In t second, session the pretest was held and in the $24^{\text {th }}$ session the posttest war run. he teach was the only assessor of students' writings in the class B. During each session, th tude its were reading their writings and the teacher gave $\mathrm{CF}$ on the spot of ading me in the papers were gathered and the teacher gave CF on them for the nets. Then were no interactions among students. The atmosphere of the class $\mathrm{B}$ as quite ring something important to mention is that the first session in the class $\mathrm{A} / \mathrm{Na}$ evoted in cach students how to use the comprehensive rating scale.

\section{RESULTS}

First, students' score in the both claseac were gat

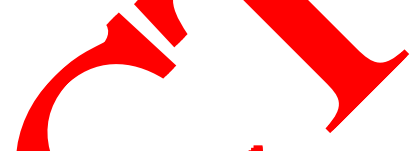

ained scores were put on SPSS to analyz and class B.

pretest and posttest. Next, the

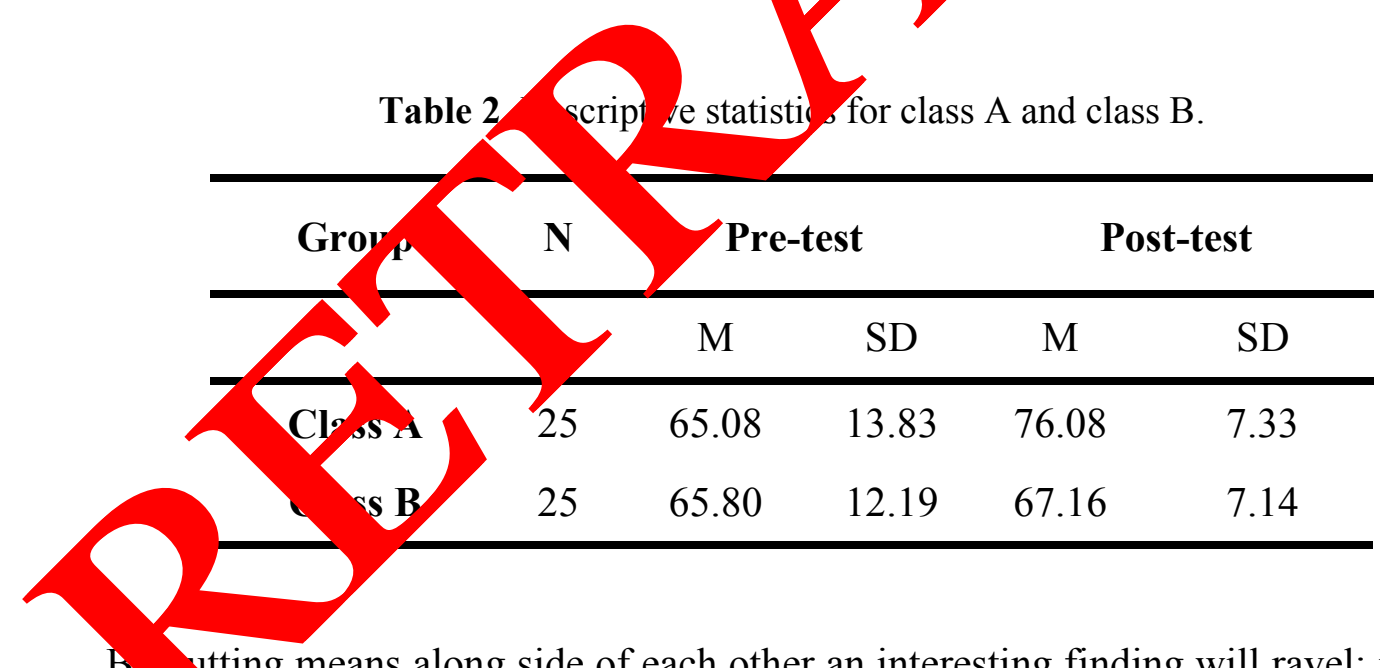

that was an means along side of each other an interesting finding will ravel: it is class A that was a to improve its accuracy mean from 65.08 to 76.08. Improving 11 credits in mean score for class A clearly showed the significant effect of Collaborative Writing on improving grammar accuracy. On the other hand, we have also an increasing improvement in the means score of class B. Class B mean score has improved from 65.80 to 67.16. Fig. 1 and Fig. 2 also show the improvement of means score in both class A and class B. although both classes have improved their mean score in posttest, class A improved it in a sharper way that shows the significant of CW tasks in EFL classroom. 
Fig.1.Means score of Class A

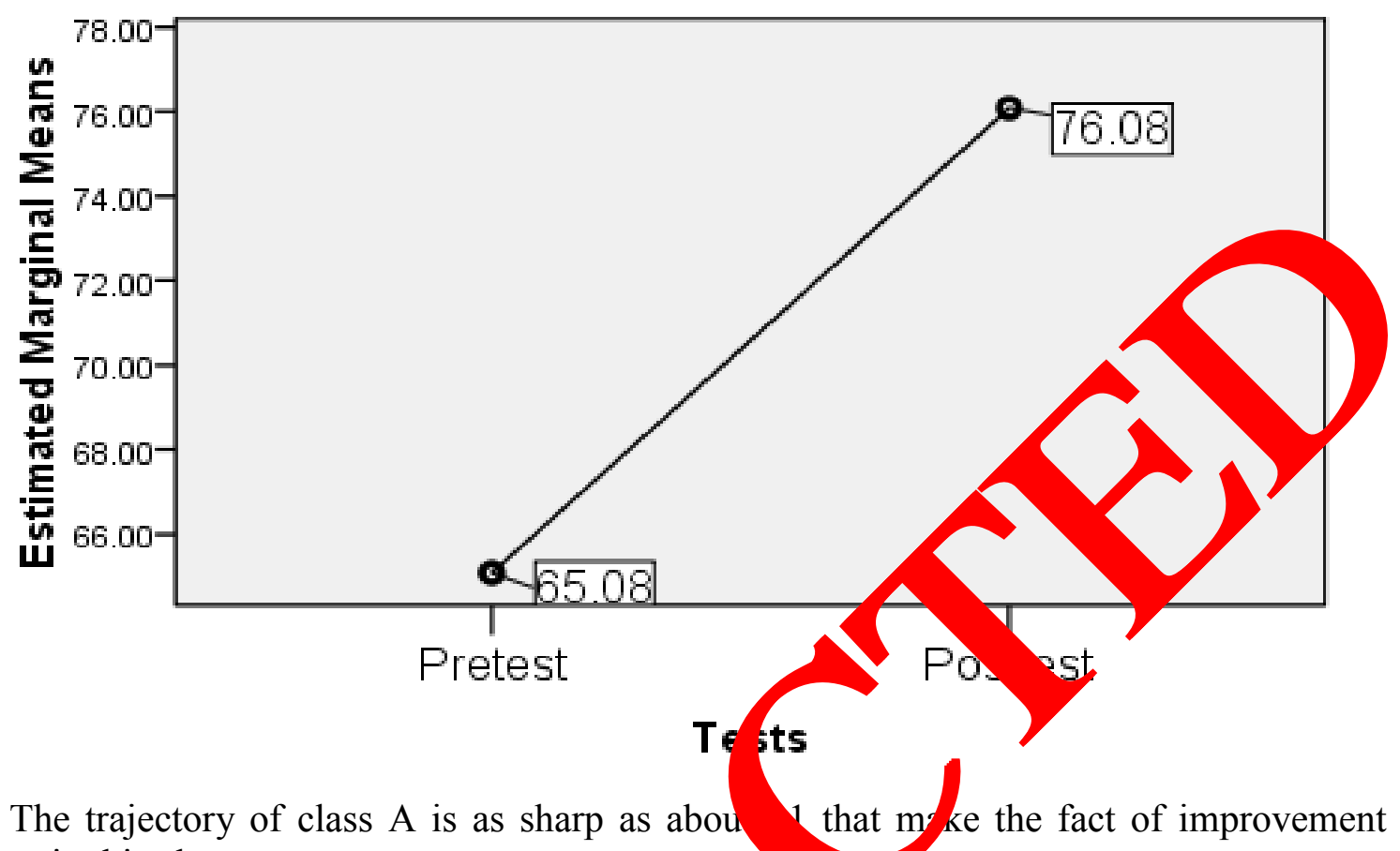
obvious in this class.

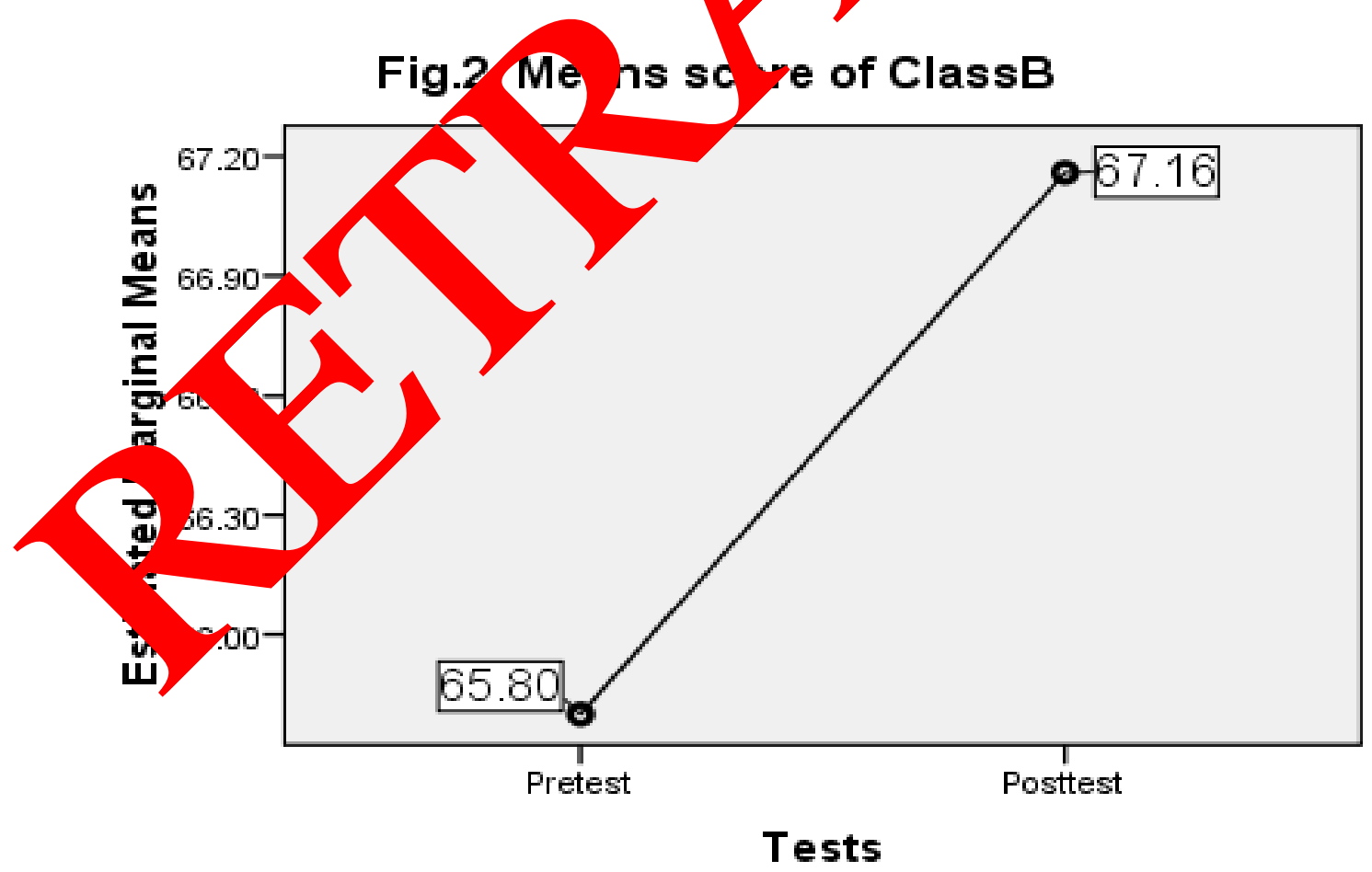


The trajectory of Fig. 2 that devoted to Class B is much less than Class A and is something about 1.36 and better to say 80 percent less than Class A. although by the illustrated statistics, it is clear that the effect of $\mathrm{CW}$ on improving grammatical accuracy is significant, we did use test of Between-Subjects Effect to answer the null hypothesis. Table 3 illustrates the obtained statistics.

Table 3. Tests of Between-Subjects Effect.

\begin{tabular}{cccc}
\hline Class & df & F & p \\
\hline Class A & 1 & 12.33 & .001 \\
Class B & 1 & .231 & .63 \\
\hline & & & \\
& &
\end{tabular}

It is quite easy to survey the hypothesis with the statistics A A NO Test 9 Between-
cts Effect. The $p=.001$ is showing that the $\mathrm{CW}$ was sig

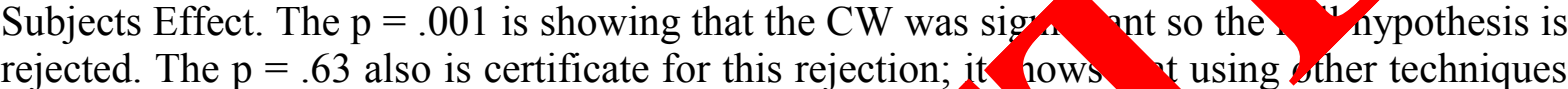
aren't significant for improving grammatical accuracy.

\section{CONCLUSIONS}

The result of the present study suppo hypothesis that Collaborative Writing has a significant effect on improving grammatica acc of the EFL students' writings, thus supporting the previous studies (Kuiken and $\mathrm{der}, 2002 \mathrm{~b}$; Storch and Wigglesworth, 2007). It was found that improving in the elm ledge or grammatical accuracy tended to be larger with the use of collaborative writin the assroom At one encounter, the participants in the CW class demonstrated large in rov accuracy (80 percent more than the other class); indicating that for dvanced- learners CW can increase the accuracy in grammatical points.

The results in icate, erall, that Collaborative Writing has a greater influence on grammatical accaracy of advan $\mathrm{EFL}$ writers than the other traditional method which was to correct studer s writ s on the spot of their reading in the classroom. As a whole, the results are consistent wit of St ch and Wigglesworth (2007), who found that the use of CW tasks improved the gra atical accuracy.

It is hportan note that the participants of this study were in their advanced level of pu enc and already have known about CW, and Analytic rating scale. Further research exam. oun proficiency level in accordance with the use of $\mathrm{CW}$ would be a useful follow up to this stu.

This study sheds lights on the way that Collaborative Writing could improve the grammatical accuracy of advanced EFL writers so it can be an excellent mean to improve writing ability in EFL context. In this way, teachers and instructors may be able to take advantage of CW in their writing classes to improve their students' grammatical accuracy and finally writing ability. 


\section{References}

[1] Alegri'a de la Colina, A., \& Garci'a Mayo, M. P.( 2007). Attention to form across collaborative tasks by low-proficiency learners in an EFL setting. In M. P. Garci'a Mayo (Ed.), Investigating tasks in foreign language learning (pp. 91-116).

Clevedon: Multilingual Matters.

[2] Bitchener J., Journal of Second Language Writing 17 (2008) 102-118.

[3] Bitchener J., Journal of Second Language Writing 18 (2009) 276-279.

[4] Bitchener J., Journal of Second Language Writing 21 (2012) 348-363.

[5] Bitchener J., Knoch U., Applied Linguistics 31 (2010) 193-214.

[6] Ferris, D. (2002). Treatment of error in second language studen witin University of Michigan Press.

[7] Hirvela, A. (2011). Writing to learn in content areas: Re a ch ins. In R. Mancho'n (Ed.), Learning-to-write and writing-to-learn in an ar altiond languas p. 159-180).
Amsterdam: John Benjamins.

[8] Hussein Meihami, International Letters of Socia d Humar stic Sciences 8 (2013) 8-23.

[9] Hussein Meihami, Bahram Meihami, Inte anal Letters of Social Humanistic Sciences 7 (2013) 86-95.

[10] Mancho' n, R. (2011). Writino arn the nguage: Issues in theory and research. In R. Mancho'n (Ed.), Learning- -writ and wi Mg-to-learn in an additional language (pp. 61-84). Amsterdam Jo

[11] Monirosadat Hoss Mohama 'san Taghizadeh, Mohamad Jafre Zainol Abedin, Elham Naseri, I ern. "al Letter, of Social and Humanistic Sciences 6 (2013) 1-12.

[12] Qi D. S., L pkin S., Jourm /Second Language Writing 10 (2001) 277-303.

[13] Sachs K. lic C., Str lies in Second Language Acquisition 29 (2007) 67-100.

[14] N., In ati hal Journal of English Studies 10 (2010) 29-46.

[10] ore Mdosari A., Language Teaching Researc, 14 (2010) 355-376.

[16] Ston N, Wigglesworth G. (2007). Writing tasks: The effect of collaboration. In M. P. Garc1) Mayo (Ed.), Investigating tasks in foreign language learning (pp. 157-177).

Clevedon: Multilingual Matters.

[17] Truscott J., Journal of Second Language Writing 16 (2007) 255-272.

[18] Van Beuningen C., De Jong N., Kuiken F., Language Learning 62 (2012) 1-41.

[19] Watanabe Y., Swain M., Language Teaching Research 12 (2008) 211-234. 
[20] Wigglesworth G., Storch N., Language Testing 26 (2009) 45-466.

[21] Wigglesworth, G., \& Storch, N. (2012). Feedback and writing development through collaboration: A socio-cultural approach. In R. Mancho'n (Ed.), L2 writing development: Multiple perspectives (pp. 69-101). New York: De Gruyter Mouton.

[22] Williams J., Journal of Second Language Writing 21 (2012) 321-331.

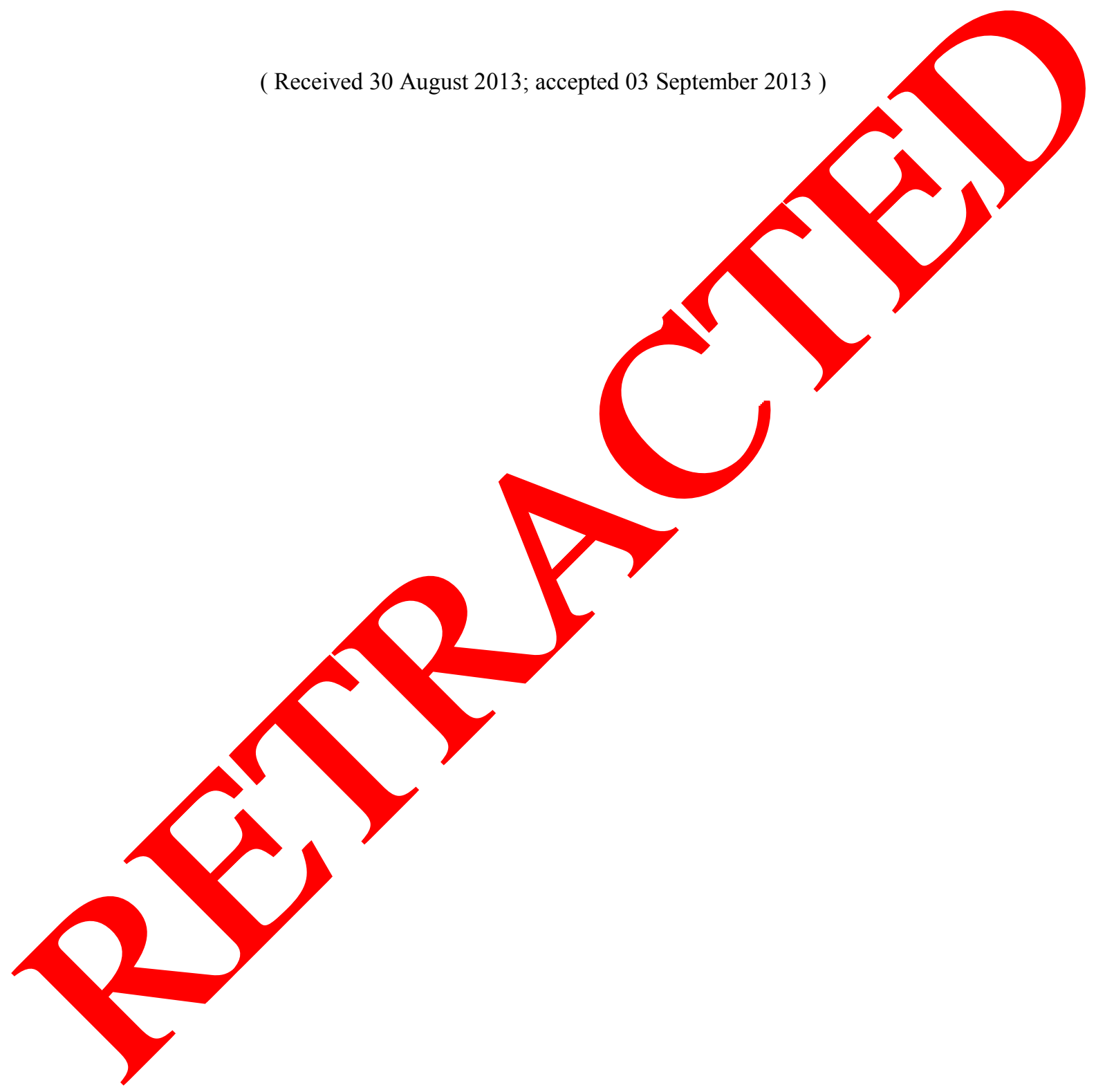

